\title{
Household-level heterogeneity of water resources within common-pool resource systems
}

\author{
Paul McCord $^{1}$, Jampel Dell'Angelo $^{2}$, Drew Gower $^{3}$, Kelly K. Caylor $^{4,5}$ and Tom Evans $^{1}$
}

\begin{abstract}
Prior work has demonstrated the ability of common property systems to sustain institutional arrangements governing natural resources over long periods of time. Much of this work has focused on irrigation systems where upstream users agree to management arrangements that distribute water resources across both upstream and downstream users. A series of design principles have been identified that tend to lead to long-term sustained water management in these types of irrigation systems. However, this prior work has focused on the aggregate outcomes of the water system, and there has been little work evaluating the heterogeneity of water delivery within irrigation systems in developing countries. Heterogeneity of water resources within these systems has implications for livelihood outcomes because it can be indicative of a social, technological, and/or biophysical element facilitating or detracting from water delivery. We present a multilevel analysis of households nested within 25 smallholder irrigation systems in Kenya. Specifically, we examine household-level water outcomes (i.e., average flow rate and reliability of water provisioning) and the community-level and household-level drivers that affect household water outcomes. These drivers include physical infrastructure, institutional infrastructure, and biophysical variables. Much of the common-pool resource literature addresses the rule clusters responsible for natural resource outcomes, but by considering an array of both institutional and physical features and the water delivery outcomes produced at the household level, we offer new explanations for water disparities within smallholder-operated irrigation systems. We further discuss the ability of user-group members to reshape their water delivery outcomes through information exchange.
\end{abstract}

Key Words: coupled infrastructure systems; governance; Irrigation systems; Kenya

\section{INTRODUCTION}

Management of common-pool resources (CPRs), such as forests, pastures, irrigation systems, and fisheries, has attracted the attention of scholars for decades. Initial warnings were of resource exhaustion for those CPRs that were neither publicly nor privately owned (Gordon 1954, Scott 1955, Hardin 1968). In the 1980 s, a number of case studies demonstrated the ability of locallevel resource users to self-organize and collectively manage CPRs, thereby challenging the speculations of earlier scholars. Although insightful as to the ability of users to work together to manage a CPR, a consistent set of rules used in cases of successful management was not discovered (Ostrom 2005). What was synthesized, however, were eight fundamental "design principles" underlying the ability of resource users to form trust in one another and sustain collective action in resource management (Ostrom 1990). Local systems of natural resource governance embodying some, but not necessarily all, of these traits would be more likely to endure over the long term.

Since the introduction of Ostrom's design principles, many diagnostic analyses have been conducted using these principles to query the sustainability of particular management regimes within diverse social-ecological systems (SESs; e.g., Morrow and Hull 1996, Coop and Brunckhorst 1999, Tucker 1999, Basurto and Ostrom 2009, Dell'Angelo et al. 2016). Irrigation systems are particularly reliant on robust institutional structures, given the challenge of achieving water equity between head-end and tailend members of the system. We define institutions as the set of rules that are actually used by a group of individuals to organize repetitive activities that produce outcomes affecting those individuals and potentially others (Ostrom 1992). Demonstrating the importance of institutions, Ostrom and Gardner (1993) revealed that even in irrigation systems where the physical infrastructure is new and well designed, water delivery inequities may be greater compared with systems with less sophisticated infrastructure but better crafted institutions.

Despite the importance of effective water management rules, some have recently expressed concerns that the persistent focus on institutional arrangements has overshadowed the role of technology and the environment in producing resource outcomes (Anderies et al. 2016). Interconnections among technological, environmental, social, economic, and institutional processes are important to consider in any SES, but irrigation systems demand particular attention to be given to technological traits (i.e., water distribution infrastructure). For example, the frequency of repairs to water distribution lines, the age of infrastructure, and the decision to expand the footprint of the irrigation system by adding new distribution lines all may play a significant role in water delivery. As a result, we use the term "coupled infrastructure system" (CIS) to denote our unit of analysis. A CIS accounts for soft human-made (institutions), physical human-made (technology), and natural (e.g., biophysical elements) infrastructures and, by explicitly acknowledging a broad array of social and physical elements, it helps to identify the interrelations that produce resource outcomes, including water delivery within irrigation systems (Anderies et al. 2016). In this paper, we treat the term "CIS" as synonymous with "SES." This is strategic, given the

\footnotetext{
${ }^{1}$ Department of Geography, Indiana University-Bloomington, ${ }^{2}$ VU University Amsterdam - Institute for Environmental Studies (IVM),

${ }^{3}$ Department of Civil \& Environmental Engineering, Princeton University, ${ }^{4}$ Bren School of Environmental Science and Management, University of California, Santa Barbara, ${ }^{5}$ Department of Geography, University of California, Santa Barbara
} 
infrastructure-heavy nature of our area of study and the utility of this term in structuring our analysis. We also use the term "CIS" in an effort to further caution against inadequate treatment of system traits in favor of others, much like the warning provided by Anderies et al. (2016).

In understanding water delivery and asymmetries between irrigation system members, the tendency has been to rely on proxies for water distribution aggregated to either an intrasystem level, such as the head- and tail-end of the system, or to the level of the irrigation system as a whole. For example, Lam (1996) assessed water delivery at the head-end and tail-end of multiple Nepalese irrigation systems through member self-reportings of water availability. Cox and Ross (2011) used agricultural productivity, measured through remotely sensed images, at the irrigation system level to assess cooperative efforts of members that facilitated adequate water delivery. Although these studies offer valuable insights in terms of system-wide outcomes produced by particular governance arrangements, the aggregation of performance measures may overlook dynamics occurring at a finer scale, and the reliance on proxies may undermine a fuller understanding of the performance measures truly under investigation, such as water delivery and equity.

In this study, we rely on household-level measurements of water delivery from 25 irrigation systems on the northern and northwestern slopes of Mount Kenya. These measurements are used to understand how elements of the CIS - that is, the institutional, technological (i.e., physical water distribution infrastructure), and biophysical infrastructures - contribute to water delivery outcomes in the form of the average rate of household water delivery and the variability of household water delivery. Our goal with this research is to both investigate CIS traits that associate with household-level water delivery and to consider water delivery asymmetries that exist among households belonging to irrigation systems. In this vein, we seek to address the following research questions:

1. How do elements of the CIS influence household-level water delivery outcomes within smallholder-operated irrigation systems?

2. How does the amount of water delivered and the reliability of delivery differ among members of the same irrigation system, as well as between irrigation systems?

By making use of data expressly collected to understand water delivery outcomes, our results are informed by the same information that water managers within the irrigation systems, unfortunately, mostly lack. Reasons for this absence of data held by decision makers are both financial and technological. Many irrigation system managers have encouraged farmer participation and zonal representation within their respective systems as a strategy to promote equitable outcomes in the absence of direct measurements of water delivery. We explore these efforts in the Discussion. Before doing this, we provide background information on the limited presence of ecology in SES studies and the need to employ ecological indicators when assessing irrigation system performance. We then describe the study area as well as our methods for data collection and statistical analysis. The results of the analysis are then presented before entering into a final discussion.

\section{The role of "ecology" in assessing performance of irrigation systems}

Research on CPRs is a challenging endeavor. Assessing the sustainability of these systems entails a recognition of complexity in the form of linear and nonlinear system feedbacks across multiple spatial and temporal scales (Berkes 2002, Young 2002). Analytical tools such as the Social-Ecological Systems Framework (Ostrom 2007) have been developed to navigate SES complexity. Yet, the SES Framework as well as SES research more generally have typically given uneven attention to its two constituent parts, with social components and processes receiving greater attention than the ecological domain (Epstein et al. 2013, Vogt et al. 2015). Rissman and Gillon (2016:7) reviewed 120 SES articles and concluded that "better integration of ecology is needed in SES research." This systematic review also found that it was more common in studies with an independent variabledependent variable connection for the outcome to be a social indicator, often a socioeconomic variable. This is likely due to the relative dominance of social scientists in SES research and the common emphasis given toward understanding how resource availability influences human decision making and socioeconomic status (Epstein et al. 2013). What is important to note here, however, is that the greater the separation between the actual resource outcome, such as water distribution equity within an irrigation system, and the dependent variable used as a proxy for performance, such as household income, the greater the opportunity for an intervening variable to skew the direct understanding of resource system performance (Small and Svendsen 1990).

To readjust the balance between social and ecological elements in SES research and avoid errors imposed by intervening variables in analyses establishing an independent variable-dependent variable connection, we describe several ecological performance indicators to evaluate irrigation systems. In this study, "ecological\&\#8221 is meant to include both environmental and ecological variables, a grouping common in the SES literature. The term "performance" is meant to indicate household-level outcomes that can be measured by their equitability, efficiency, or ability to support livelihood security (Berkes and Folke 1994). Civil engineering studies, in research concentrating on rural development, have paid extensive attention to issues of water delivery within a range of systems. Molden and Gates (1990) provided definitions for several measures of irrigation system performance. The authors identified measures of adequacy (i.e., delivery of the necessary amount of water over an area served by the irrigation system), efficiency (i.e., conservation of water by ensuring that water deliveries equal water requirements), dependability (i.e., the temporal variability in the amount of water delivered compared with the amount required), and equity (i.e., the spatial variability in the amount of water delivered compared with the amount required) as indicators of irrigation system performance. Relying on multiple field measurements of water flow at various times and locations, the authors then applied these measures to evaluate performance of irrigation systems in Sri Lanka and Egypt.

In this study, we use household-level measurements of water delivery to assess the dependability of water flow (i.e., the variation in water delivery) and the adequacy of water flow (i.e., the average flow rate). Directly employing ecological indicators 
of irrigation system performance reduces the potential for intervening variables to complicate our assessment of the contextual drivers influencing water delivery in a collection of irrigation systems in the Mount Kenya region.

\section{STUDY AREA}

The 25 irrigation systems, known as community water projects (CWPs) in the area of study, are found on the northern and northwestern slopes of Mount Kenya in the Upper Ewaso Ng'iro basin (Fig. 1). Over very short distances, the conditions within the basin change significantly: precipitation dramatically decreases from atop Mount Kenya to the northwestern reaches of the study area, and, moving from the CWPs closest to the mountain to those further downstream, livelihood practices transition from sedentary farming to practices more focused on pastoralism (McCord et al. 2015). Smallholders primarily rely on rainfall when cultivating crops, but use irrigation water provided by their CWP to supplement rainfall, extend growing seasons, and span dry spells. The basin's population grew from 50,000 in 1960 to 500,000 in 2000 (Ngigi et al. 2007), which in turn reduced streamflow in the basin's major rivers (Liniger et al. 2005).

Fig. 1. Study area. Note: WRUA boundaries have been approximated. CWP locations are presented with their centroids. Isohyets represent average yearly precipitation in millimeters.

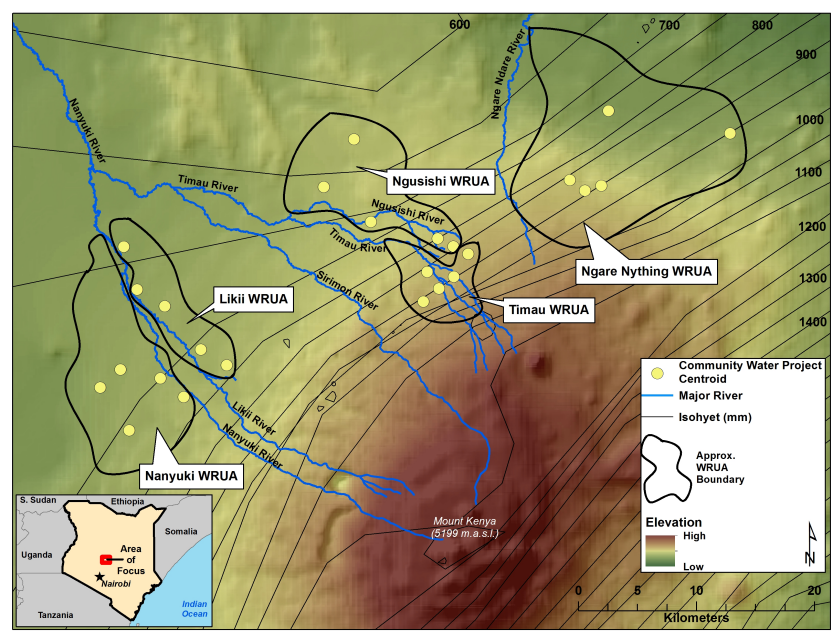

The coupled infrastructure system: physical human-made infrastructure traits of the community water projects

All CWPs receive their water from one of the major rivers within the study area, or, in some cases, a natural spring. The CWPs are typically located several kilometers from their water source and rely on polyvinyl chloride (PVC) pipes ranging in size from 7.6$20.3 \mathrm{~cm}$ (3-8 inches) to carry water from the source to the CWP head-end. Once in the CWP, water is either held in a large tank or reservoir, or it is gravity-fed through a network of PVC pipes making up the distribution lines of the irrigation system (Fig. 2). Water is then fed from these pipes to each homestead through individual household lines; note that the individual household lines are not shown in Fig. 2. The distribution lines of the CWP are buried and range in diameter in order to maintain pressure.
Water held in the CWP's tank or reservoir is often released to households during times of water scarcity. The water distribution networks under investigation here differ from the irrigation systems in studies such as Lam $(1996,1998)$, which use open and often unlined ditches to transport water.

Physical human-made infrastructure characteristics vary greatly across the CWPs (Table 1). Age of the CWP and the number of distribution lines are two such examples. The oldest CWP was established in the early 1970s and began running water to its members in 1980, whereas the youngest was formed in 2008 and only began distributing water to its members in 2011. Depending on the level of maintenance given to distribution lines, pipes within older CWPs may be more susceptible to leakage and result in less reliable household flow. The number of distribution lines range from a complex configuration of 25 lines (this is the CWP shown in Fig. 2) to a single, straight conduit with households affixed at various points.

\section{The coupled infrastructure system: institutional infrastructure traits of the community water projects}

Water governance in the Upper Ewaso Ng'iro basin, as well as throughout Kenya, is multilevel: water resource users associations (WRUAs) oversee activities at the subcatchment level and generally coordinate water withdrawals from a single river or spring (see Fig. 1), whereas CWPs manage water operations within their communities. A WRUA creates a forum for the CWPs of a particular subcatchment to communicate, monitor water use, and resolve conflicts (Dell'Angelo et al. 2014). WRUAs play an important role during dry periods as they coordinate water rationing schedules among the CWPs of their subcatchment and ensure that a community only takes water when they are scheduled to do so. These dry periods typically occur in January and February and during a longer episode from late July to September. In some subcatchments, WRUA personnel periodically patrol the riparian zone to assess water levels and safeguard against excessive withdrawals. Despite the importance of WRUAs in water management, our analysis here focuses primarily on water management at the community level, thus concentrating on the institutions devised by CWP management committees. More detailed attention is given to WRUAs in Baldwin et al. (2016).

The management committee of a CWP, typically consisting of a chairperson, vice-chairperson, secretary, treasurer, and other individuals elected to represent households belonging to particular sections of the CWP, is responsible for designing procedures that ensure household water availability during both the wet and dry seasons. In the absence of water meters affixed to distribution lines to provide flow readings, which are absent from CWPs due both to financial reasons and obstruction concerns stemming from the large amount of sediment in pipes, the management committee relies on zonal representatives to report household-level water delivery concerns (McCord et al. 2016). All 25 CWPs use some form of information transfer from these representatives to the management committee in order to prioritize maintenance activities and resolve concerns of poor water delivery, such as low or unreliable flow. System maintenance is typically carried out by a paid employee of the CWP known as the caretaker.

Aside from relying on representatives from particular branches in the CWP to report water concerns, the management committee 
Table 1. Select physical infrastructure attributes of CWPs

\begin{tabular}{|c|c|c|c|c|c|c|}
\hline $\mathrm{CWP}$ name $^{\dagger}$ & WRUA name & Age of CWP & Number of lines & $\begin{array}{c}\text { Total length of } \\
\text { CWP distribution } \\
\text { lines }(\mathrm{m})\end{array}$ & $\begin{array}{c}\text { Areal extent of } \\
\text { CWP }\left(\mathrm{km}^{2}\right)\end{array}$ & $\begin{array}{c}\text { Presence of at least } \\
\text { one water storage } \\
\text { tank }\end{array}$ \\
\hline L-CWP-1 & Likii & 16 & 4 & 2043.1 & 0.4 & Yes \\
\hline L-CWP-2 & Likii & 31 & 2 & 4735.5 & 1.5 & No \\
\hline L-CWP-3 & Likii & 12 & 3 & 9698.5 & 5.5 & No \\
\hline L-CWP-4 & Likii & 11 & 7 & 6545.0 & 1.8 & Yes \\
\hline L-CWP-5 & Likii & 10 & 8 & 9467.3 & 5.3 & Yes \\
\hline Nan-CWP-1 & Nanyuki & 26 & 14 & $22,078.4$ & 9.1 & Yes \\
\hline Nan-CWP-2 & Nanyuki & 18 & 20 & $37,375.0$ & 15.9 & Yes \\
\hline Nan-CWP-3 & Nanyuki & 19 & 25 & $36,119.2$ & 17.7 & Yes \\
\hline Nan-CWP-4 & Nanyuki & 24 & 27 & $15,807.8$ & 3.6 & Yes \\
\hline Nan-CWP-5 & Nanyuki & 9 & 20 & $17,611.6$ & 7.1 & No \\
\hline Ngu-CWP-1 & Ngusishi & 15 & 3 & 2576.4 & 0.2 & No \\
\hline Ngu-CWP-2 & Ngusishi & 14 & 8 & $22,157.2$ & 24.9 & Yes \\
\hline Ngu-CWP-3 & Ngusishi & 7 & 5 & 834.5 & 0.1 & Yes \\
\hline Ngu-CWP-4 & Ngusishi & 14 & 6 & 2836.3 & 0.4 & No \\
\hline Ngu-CWP-5 & Ngusishi & 5 & 8 & $10,074.3$ & 4.1 & Yes \\
\hline NN-CWP-1 & Ngare Nything & 14 & 15 & 8214.7 & 1.2 & Yes \\
\hline NN-CWP-2 & Ngare Nything & 12 & 11 & 6661.7 & 1.3 & No \\
\hline NN-CWP-3 & Ngare Nything & 15 & 1 & 983.3 & 0.1 & Yes \\
\hline NN-CWP-4 & Ngare Nything & 27 & 7 & 2210.4 & 0.1 & No \\
\hline NN-CWP-5 & Ngare Nything & 41 & 24 & $59,396.7$ & 57.6 & Yes \\
\hline T-CWP-1 & Timau & 14 & 4 & 2399.3 & 0.4 & No \\
\hline T-CWP-2 & Timau & 31 & 3 & 1755.6 & 0.1 & No \\
\hline T-CWP-3 & Timau & 27 & 2 & 3947.6 & 0.5 & No \\
\hline T-CWP-4 & Timau & 30 & 11 & $10,670.8$ & 5.2 & Yes \\
\hline T-CWP-5 & Timau & 29 & 12 & 5599.8 & 1.2 & Yes \\
\hline
\end{tabular}

${ }^{\dagger}$ Pseudonym used for CWP name.

Fig. 2. The layout of a CWP showing both the position along a river (right) and the configuration of distribution lines (left).

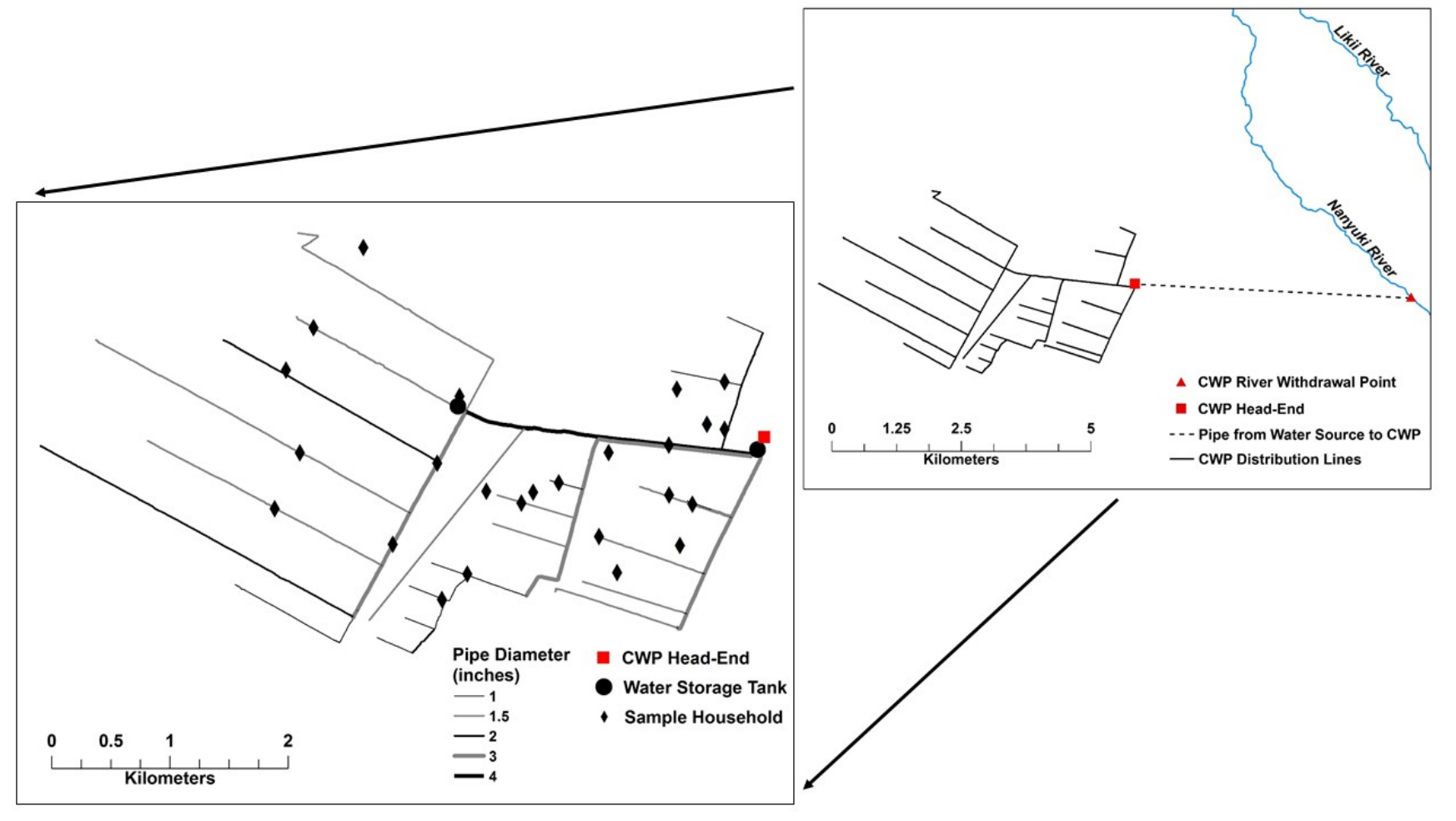


Table 2. Select institutional infrastructure attributes of CWPs

\begin{tabular}{|c|c|c|c|c|c|c|c|}
\hline $\mathrm{CWP}_{\text {name }}^{\dagger}$ & $\begin{array}{l}\text { WRUA } \\
\text { abbreviation }\end{array}$ & $\begin{array}{l}\text { CWP allows new } \\
\text { members }\end{array}$ & $\begin{array}{l}\text { Person must be } \\
\text { member of } \\
\text { particular village to } \\
\text { join CWP }\end{array}$ & $\begin{array}{l}\text { Caretaker must } \\
\text { monitor water } \\
\text { use }\end{array}$ & $\begin{array}{l}\text { Water cut off } \\
\text { for tampering } \\
\text { with pipes }\end{array}$ & $\begin{array}{l}\text { Monetary fine if } \\
\text { no labor } \\
\text { provided for } \\
\text { CWP } \\
\text { maintenance }\end{array}$ & $\begin{array}{l}\text { Wet season water } \\
\text { rotation strategy }\end{array}$ \\
\hline L-CWP-1 & $\mathrm{L}$ & $\mathrm{No}$ & $\mathrm{No}$ & $\mathrm{No}$ & Yes & Yes & NR \\
\hline L-CWP-2 & $\mathrm{L}$ & Yes & No & No & Yes & Yes & NR \\
\hline L-CWP-3 & $\mathrm{L}$ & Yes & $\mathrm{No}$ & Yes & Yes & Yes & WSWR \\
\hline L-CWP-4 & $\mathrm{L}$ & Yes & No & No & Yes & $\mathrm{No}$ & NR \\
\hline L-CWP-5 & $\mathrm{L}$ & Yes & No & No & $\mathrm{No}$ & Yes & WSWR \\
\hline Nan-CWP-1 & Nan & Yes & Yes & Yes & Yes & Yes & WSWR \\
\hline Nan-CWP-2 & Nan & Yes & Yes & No & No & Yes & WSWR \\
\hline Nan-CWP-3 & Nan & Yes & $\mathrm{No}$ & Yes & Yes & $\mathrm{No}$ & WSWR \\
\hline Nan-CWP-4 & Nan & Yes & Yes & Yes & $\mathrm{No}$ & $\mathrm{No}$ & NR \\
\hline Nan-CWP-5 & Nan & Yes & No & Yes & No & Yes & NR \\
\hline Ngu-CWP-1 & $\mathrm{Ngu}$ & Yes & No & Yes & $\mathrm{No}$ & Yes & NR \\
\hline Ngu-CWP-2 & $\mathrm{Ngu}$ & Yes & Yes & No & Yes & No & WSWR \\
\hline Ngu-CWP-3 & $\mathrm{Ngu}$ & No & $\mathrm{No}$ & No & No & Yes & NR \\
\hline Ngu-CWP-4 & $\mathrm{Ngu}$ & No & No & Yes & No & No & WSWR \\
\hline Ngu-CWP-5 & $\mathrm{Ngu}$ & Yes & No & No & $\mathrm{No}$ & Yes & WSWR \\
\hline NN-CWP-1 & NN & Yes & Yes & Yes & Yes & Yes & WSWR \\
\hline NN-CWP-2 & $\mathrm{NN}$ & No & No & Yes & Yes & Yes & WSWR \\
\hline NN-CWP-3 & $\mathrm{NN}$ & Yes & No & Yes & Yes & Yes & WSWR \\
\hline NN-CWP-4 & $\mathrm{NN}$ & Yes & No & No & $\mathrm{No}$ & Yes & NR \\
\hline NN-CWP-5 & $\mathrm{NN}$ & Yes & No & Yes & $\mathrm{No}$ & Yes & WSWR \\
\hline T-CWP-1 & $\mathrm{T}$ & No & No & Yes & No & No & WSWR \\
\hline T-CWP-2 & $\mathrm{T}$ & Yes & Yes & No & No & Yes & WSWR \\
\hline T-CWP-3 & $\mathrm{T}$ & No & $\mathrm{No}$ & No & No & Yes & WSWR \\
\hline T-CWP-4 & $\mathrm{T}$ & No & $\mathrm{No}$ & No & Yes & $\mathrm{No}$ & WSWR \\
\hline T-CWP-5 & $\mathrm{T}$ & No & No & Yes & No & Yes & WSWR \\
\hline
\end{tabular}

Pseudonym used for CWP name.

"WRUA abbreviation: L=Likii, Nan=Nanyuki, Ngu=Ngusishi, NN=Ngare Nything, T=Timau.

${ }^{\S}$ Wet season water rotation strategy: NR = No rotation (CWP does not enforce water rotation at any point in the year), WSWR $=\mathrm{CWP}$ enforces a wet season water rotation strategy (and likely enforces a dry season rotation as well).

also crafts water use and membership rules to take on collective action challenges, i.e., the difficulties that arise due to dissimilarities between individual and group incentives. These challenges may take the form of appropriation dilemmas, where individual decisions to excessively use water reduce availability to all other users, or provision dilemmas, where individuals may choose to freeride rather than provide labor input to maintain the system's physical infrastructure. Rules crafted to overcome the appropriation dilemma include those specifying the actions that are and are not permissible when using water as well as those that specify the penalty for violating an agreed-upon water use rule. The provision dilemma is addressed with rules specifying the regularity with which labor must be committed for infrastructure repairs as well as the penalty for failure to contribute labor. Several of these institutions are listed in Table 2. Collective action may also be challenged by certain features of an irrigation system's membership, such as a large, heterogeneous membership that is particularly unengaged with water issues. We include several variables in our statistical analysis, described below, to account for these obstacles.

A final notable rule crafted by the management committee explains the process by which water is rationed amongst the CWP members when it is in short supply. This typically involves a rotation schedule where water may only pass through a particular line once or twice a week. For example, a CWP with three major lines, A, B, and C, may only allow water to pass to the members of line A on Monday and Thursday, to the members of line B on Tuesday and Friday, to the members of line C on Wednesday and Saturday, and to no members on Sunday by closing all lines. The caretaker of the CWP is often responsible for opening and closing lines during the rotation process. In CWPs with smaller memberships, such rotation programs only occur during the driest months, whereas CWPs with larger memberships enforce rotations year round.

\section{DATA AND METHODS}

\section{Data collection}

The data to evaluate household-level water delivery were collected during an 8-mo period from the end of May 2013 to the end of January 2014. These data group into four categories: household survey, manager survey, CWP mapping, and household water flow data.

\section{Household survey data}

Household surveys were administered to 750 smallholder farmers across the 25 CWPs from the end of May 2013 to the beginning of September 2013. Kenyan enumerator teams administered the surveys and were accompanied by American research assistants and graduate students. In CWPs with large memberships, surveys 
Table 3. Data collection summary

\begin{tabular}{|c|c|c|c|}
\hline Data category & Period of collection & Total observations & Select information provided \\
\hline Household surveys & $\begin{array}{l}\text { May 2013- } \\
\text { September } 2013\end{array}$ & 750 & $\begin{array}{l}\text { - Number of years in current location } \\
\text { - Water storage assets } \\
\text { - Agricultural practices } \\
\text { - Household geographic location }\end{array}$ \\
\hline Manager surveys & $\begin{array}{l}\text { June } 2013 \text { - } \\
\text { September } 2013\end{array}$ & 25 & $\begin{array}{l}\text { - Rules-in-use, including water rotation strategies, penalties for rule } \\
\text { violation, monitoring obligations, and constraints on membership } \\
\text { - Community-level water storage assets }\end{array}$ \\
\hline CWP mapping & $\begin{array}{l}\text { June } 2013- \\
\text { September } 2013\end{array}$ & 25 & $\begin{array}{l}\text { - Geospatial data set of pipe locations } \\
\text { - Total number and diameter of CWP distribution lines } \\
\text { - Total length of CWP distribution lines } \\
\text { - Areal coverage of CWP } \\
\text { - CWP intake location }\end{array}$ \\
\hline Household water flow & $\begin{array}{l}\text { July } 2013 \text { - January } \\
2014\end{array}$ & $370^{\dagger}$ & $\begin{array}{l}\text { - Average flow rate }(\mathrm{L} / \mathrm{min}) \text { for all sampled households } \\
\text { - Coefficient of variation of flow rate for all sampled households }\end{array}$ \\
\hline
\end{tabular}

were conducted with at least 30 households when possible, whereas in CWPs with smaller memberships (i.e., less than 60 members), at least $50 \%$ of the member households were sampled. Surveys had a duration of approximately $45 \mathrm{~min}$ and included questions concerning water use activities, agricultural practices, and household and community attributes (Table 3). In an effort to obtain a representative sample of households, survey teams visited households along all major distribution lines within each CWP. Thus, if a CWP had three major lines, enumerators would split themselves among these three lines. While sampling along each distribution line, enumerators visited every third household in order to avoid clustering the sampled households. At the conclusion of each survey, a GPS point was recorded to geolocate responses.

The household survey data are the primary data source we used to construct household-level variables for a multilevel regression model, which is described below.

\section{Manager survey data}

The chairperson, or in some cases another member of the management committee, of each CWP was surveyed to gain an understanding of the community's rules-in-use as well as community assets (e.g., water storage tanks and reservoirs) and threats facing the CWP, such as droughts (Table 3). Additionally, these surveys provided information concerning the CWP's physical infrastructural make-up, such as the size and age of distribution lines. Surveys were administered from the beginning of June 2013 to beginning of September 2013.

The data derived from the manager surveys are used to determine the age of CWPs and, most significantly, to inform our construction of institutional variables that are used in a multilevel model.

\section{Community water project mapping}

The distribution lines of each CWP were mapped over a 2-mo period, from June to August 2013. A high-precision GPS unit was used to record pipe locations. Mapping was aided by the CWP's caretaker who guided the process and provided details concerning pipe diameter.
From this exercise, we have information on the number of distribution lines, total pipe length, pipe diameter, and areal coverage of the CWP, which account for the physical humanmade infrastructure variables in the multilevel regression model described below. Furthermore, the mapping effort provided geospatial information that was used to calculate the elevation gradient over which water traversed.

\section{Household water flow data}

To gauge water delivery at individual households, flow measurements were taken at a subset of homes within each CWP from July 2013 to the end of January 2014. In smaller CWPs, ten households were measured, whereas in larger CWPs, flow was measured at 20 households. Homes that took part in the water flow measurements had also taken part in the household survey. When identifying candidates for the water flow sample, we ensured that we selected households at the head-end, middle, and tail-end of the CWP.

Initial efforts to measure water delivery relied on flow sensors affixed to individual household lines; however, the large amount of sediment in the pipes resulted in water flow becoming obstructed by the sensors. As a result, discrete flow measurements were instead taken once a week by recording the time needed to fill an 18-L bucket. To ensure comparability across weeks, measurements were made from the same line after all other household lines and taps had been turned off. In total, water flow was measured at 370 households (Table 3); however, we were compelled to stagger the starting date of each CWP's flow measurement campaign due to logistical challenges. This resulted in a greater number of household measurements within some CWPs than others. For example, in the CWP that was last to begin flow measurements, each of the 20 sampled households were visited a total of 21 times from 9 September 2013 to 24 January 2014, whereas in the CWP that was first to begin flow measurements, each of the 20 sampled households were visited a total of 28 times from 9 July 2013 to 29 January 2014.

These flow measurements are used to construct the dependent variables for the multilevel regression model. Furthermore, they 
Fig. 3. Representation of steps to calculate average household flow rate (top schematic) and the coefficient of variation of household flow rate (bottom schematic).
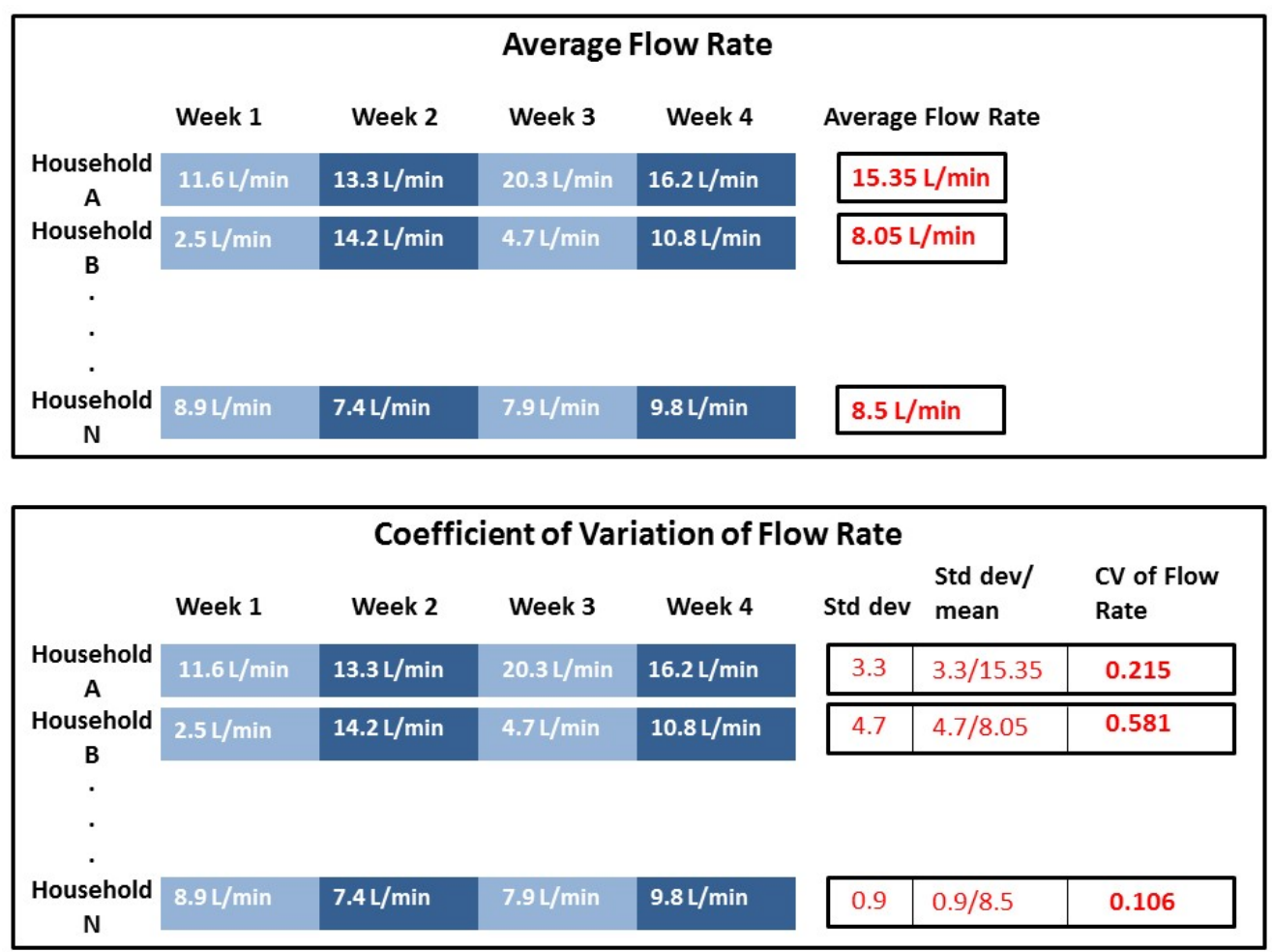

inform our investigation of water asymmetries both within and across CWPs, which we address in the Results section.

\section{Multilevel regression model}

Data at both the community and household level were included in a multilevel regression. We did not include WRUA level variables in the analysis for reasons specified below. This section summarizes the variables at the community and household level believed to influence water delivery and then describes the multilevel model itself.

\section{Dependent variables: average water flow and water flow variability}

Two household-level dependent variables were constructed: average water flow and water flow variability. Both of these variables will help to understand the contextual drivers of water delivery (research question 1) and household water asymmetries (research question 2) within a CWP. Flow variability relates to the "dependability" performance measure, which Molden and Gates (1990) described as the temporal uniformity of the delivered amount of water. Average flow rate is loosely related to the measure of "adequacy" from the same study, but we do not incorporate crop water demand into this measurement as Molden and Gates (1990) propose.

We calculated average flow rate simply by finding the average flow (measured in $\mathrm{L} / \mathrm{min}$ ) for each of the sampled households across the total number of weeks in which measurements were taken (example given in Fig. 3). We assessed flow variability by calculating the coefficient of variation $(\mathrm{CV})$ of water flow for each of the sampled households. This was done by calculating the standard deviation of flow for each household across the total number of measurement weeks. Standard deviation of flow was then divided by average flow for each household, which provided the household CV of water flow (Fig. 3). Descriptive statistics of both of these performance measures are found in Table 4.

Independent variables: multilevel coupled infrastructure system drivers of water delivery outcomes

We have split the CIS explanatory variables into four categories for purposes of clarity: physical human-made infrastructure; institutional infrastructure; biophysical traits; and other pathways, including collective action obstacles (Table 4). Within each category, we have indicated whether or not the driver is a community-level variable (level 2) or household-level variable (level 1). Several of the variables within the "Institutional infrastructure" category represent a summation of total conditions, total sanctions, or total number of monitoring entities. For example, water use may be monitored by WRUA personnel, the CWP caretaker, and representatives of each distribution line in one CWP (three monitoring entities), whereas another CWP may only monitor water use through the caretaker (one monitoring entity). Lam (1998) employed this summation approach in his study of resource outcomes as well. Some of the more commonly occurring penalties or membership criteria are listed in the notes portion of Table 4 for these summation variables. All explanatory variables listed in Table 4 were included in the multilevel models, described below, except "Total pipe length (m)." This variable was eliminated because it was highly 
Table 4. Summary statistics

\begin{tabular}{|c|c|c|c|c|c|}
\hline Variable name & Variable description & Mean & SD & Min & Max \\
\hline \multicolumn{6}{|l|}{ Dependent variables } \\
\hline Average flow rate $(\mathrm{L} / \mathrm{min})^{\mathrm{HH}}$ & Refer to section 4.2 .1 & 17.8510 & 14.451 & 3.8081 & 161.51 \\
\hline $\mathrm{CV}$ of water flow ${ }^{\mathrm{HH}}$ & Refer to section 4.2 .1 & 0.2816 & 0.1782 & 0.0460 & 1.6034 \\
\hline \multicolumn{6}{|c|}{ Independent variables: Physical human-made infrastructure } \\
\hline Areal coverage $\left(\mathrm{km}^{2}\right)^{\mathrm{CWP}}$ & Total area occupied by the CWP in $\mathrm{km}^{2}$ & 6.612 & 12.121 & 0.0352 & 57.612 \\
\hline $\begin{array}{l}\text { Number of distribution } \\
\text { lines }\end{array}$ & Total number of CWP distribution lines & 10.00 & 7.632 & 1.00 & 27.00 \\
\hline $\begin{array}{l}\text { Pipe size at water source } \\
\text { abstraction point (inches) }\end{array}$ & $\begin{array}{l}\text { Diameter of pipe where water is abstracted from } \\
\text { river/spring }\end{array}$ & 5.854 & 1.592 & 2.00 & 8.00 \\
\hline Total pipe length $(\mathrm{m})^{\mathrm{CWP}}$ & Sum of all distribution lines in meters & $12,072.0$ & 13,830 & 834.53 & 59,396 \\
\hline $\begin{array}{l}\text { Distance wtr source to head- } \\
\text { end }(\mathrm{m}) \text { CWP }\end{array}$ & $\begin{array}{l}\text { Distance from river or spring to CWP head-end } \\
\text { (m) }\end{array}$ & 3277.702 & $3,064.5$ & 1.00 & 11,928 \\
\hline Age of $\mathrm{CWP}^{\mathrm{CWP}}$ & Age of water project & 18.84 & 8.987 & 5.00 & 41.00 \\
\hline $\begin{array}{l}\text { Distance head-end to } \\
\text { household }(\mathrm{m})^{\mathrm{HH}}\end{array}$ & Distance from CWP head-end to household (m) & 2194.12 & $1,382.9$ & 49.552 & 6870.2 \\
\hline \multicolumn{6}{|c|}{ Independent variables: Institutional infrastructure } \\
\hline Membership change ${ }^{\text {CWP }}$ & Does the CWP allow new members to join? & 0.6800 & 0.4665 & $0.00(\mathrm{No})$ & 1.00 (Yes) \\
\hline Wet season rotation ${ }^{\mathrm{CWP}}$ & $\begin{array}{l}\text { Does the CWP rotate water during the wet } \\
\text { season? }\end{array}$ & 0.6800 & 0.4665 & $0.00(\mathrm{No})$ & 1.00 (Yes) \\
\hline $\begin{array}{l}\text { Membership criteria: Total } \\
\text { conditions }\end{array}$ & $\begin{array}{l}\text { Count of conditions to be met in order to join } \\
\text { CWP }^{\dagger}\end{array}$ & 2.5189 & 0.5741 & 2.00 & 4.00 \\
\hline $\begin{array}{l}\text { Pipe damaging: Total } \\
\text { sanctions }\end{array}$ & Count of sanctions imposed for damaging pipes ${ }^{\star}$ & 1.3919 & 0.800 & 1.00 & 4.00 \\
\hline $\begin{array}{l}\text { Failure to pay fee: Total } \\
\text { sanctions }\end{array}$ & $\begin{array}{l}\text { Count of sanctions imposed for failing to pay } \\
\text { monthly fee }\end{array}$ & 0.9459 & 0.6882 & 0.00 & 2.00 \\
\hline $\begin{array}{l}\text { Failure to work: Total } \\
\text { sanctions }\end{array}$ & $\begin{array}{l}\text { Count of sanctions imposed for failing to provide } \\
\text { laborl }\end{array}$ & 1.2270 & 0.513 & 0.00 & 2.00 \\
\hline $\begin{array}{l}\text { Water use monitoring: Total } \\
\text { entities } \mathrm{CWP}\end{array}$ & $\begin{array}{l}\text { Count of different groups responsible for } \\
\text { monitoring illegal water use }\end{array}$ & 2.2405 & 1.2650 & 0.00 & 5.00 \\
\hline \multicolumn{6}{|c|}{ Independent variables: Biophysical traits } \\
\hline $\begin{array}{l}\text { Elevation gradient water } \\
\text { source to intake }\end{array}$ & $\begin{array}{l}\text { Elevation gradient from water source to CWP } \\
\text { intake }\end{array}$ & 0.0332 & 0.0299 & 0.00 & 0.1100 \\
\hline $\begin{array}{l}\text { Elevation gradient intake to } \\
\text { household }\end{array}$ & $\begin{array}{l}\text { Elevation gradient from CWP intake to } \\
\text { household }\end{array}$ & 0.0347 & 0.0228 & -0.0432 & 0.1081 \\
\hline \multicolumn{6}{|c|}{ Independent variables: Other pathways (including collective-action obstacles) } \\
\hline Total members & Total CWP membership & 272.6838 & 237.84 & 10.00 & 928.00 \\
\hline Count of tribes ${ }^{\mathrm{CWP}}$ & Count of CWP's tribal groups & 2.1378 & 0.9928 & 1.00 & 5.00 \\
\hline $\begin{array}{l}\text { Count of water storage } \\
\text { devices }\end{array}$ & $\begin{array}{l}\text { Count of } \mathrm{HH} \text { storage devices (large tanks and } \\
\text { reservoirs) }\end{array}$ & 0.5973 & 0.6388 & 0.00 & 2.00 \\
\hline Years at residence ${ }^{\mathrm{HH}}$ & Number of years at residence & 19.9270 & 11.208 & 2.00 & 60.00 \\
\hline Meeting attendance ${ }^{\mathrm{HH}}$ & $\begin{array}{l}\text { Number of water meetings attended in last year } \\
\text { (categorical) }\end{array}$ & $\begin{array}{l}2-5 \text { (most } \\
\text { common group) }\end{array}$ & & Never & $6+$ \\
\hline
\end{tabular}

$\overline{\mathrm{CWP} / \mathrm{HH}}$ Indicates whether the variable is at the community or household level.

${ }^{\dagger}$ Most frequently reported conditions: Must own land (24 CWPs), must pay membership fee (24).

${ }^{\ddagger}$ Most frequently reported pipe damaging sanctions: Water is disconnected (11).

${ }^{\S}$ Most frequently reported sanctions for failing to pay monthly fee: Water is disconnected (17).

${ }^{\prime}$ Most frequently reported sanctions for failing to contribute labor: Monetary sanctions are imposed (18), water is disconnected (9).

'Entities most often involved in monitoring: Management committee members (21), caretaker (13), neighbors (9).

correlated with "Areal coverage $\left(\mathrm{km}^{2}\right)$," "Total members," and "Number of distribution lines."

The hypothesized relationships between the independent variables and the water flow outcomes are specified in Table 5. Looking first at the variables in the "Physical human-made infrastructure" category, our expectations were influenced by studies such as Makurira et al. (2007), which found that larger, more complex distribution networks within their study had higher incidences of water conveyance loss. Therefore, variables that indicated that water would be traveling extended distances to reach households (e.g., "Areal coverage" or "Distance intake to household") or that water would traverse a complex network of pipes (e.g., "Number of distribution lines") were expected to slow average water flow and increase water flow variability. The age of the CWP also was anticipated to influence water flow outcomes, with older pipe networks expected to have higher incidences of 
Table 5. Hypothesized relationships

\begin{tabular}{|c|c|c|c|}
\hline$\overline{\text { Category }^{\dagger}}$ & Parameter & $\begin{array}{l}\text { Hypothesized relationship with } \\
\text { average household flow rate }\end{array}$ & $\begin{array}{l}\text { Hypothesized relationship with } \\
\text { household CV of water flow }\end{array}$ \\
\hline \multirow{6}{*}{ PHMI } & Areal coverage of $\mathrm{CWP}$ & Negative & Positive \\
\hline & Number of distribution lines & Negative & Positive \\
\hline & Pipe size at water source abstraction point & Positive & Negative \\
\hline & Distance water source to head-end & Negative & Positive \\
\hline & Age of CWP & Negative & Positive \\
\hline & Distance head-end to household & Negative & Positive \\
\hline \multirow{7}{*}{ II } & Membership change (allows membership growth) & Negative & Positive \\
\hline & Wet season rotation (rotates during WS) & Negative & Positive \\
\hline & Membership criteria: Total conditions & Positive & Negative \\
\hline & Pipe damaging: Total sanctions & Positive & Negative \\
\hline & Failure to pay fee: Total sanctions & Positive & Negative \\
\hline & Failure to work: Total sanctions & Positive & Negative \\
\hline & Water use monitoring: Total entities & Positive & Negative \\
\hline \multirow[t]{2}{*}{ BT } & Elevation gradient water source to intake & Positive & Negative \\
\hline & Elevation gradient intake to household & Positive & Negative \\
\hline \multirow{5}{*}{$\mathrm{CA} / \mathrm{OP}$} & Total members & Negative & Positive \\
\hline & Count of tribes & Negative & Positive \\
\hline & Count of water storage devices & Negative & Positive \\
\hline & Years at residence & Positive & Negative \\
\hline & Meeting attendance (more frequent attendance) & Positive & Negative \\
\hline
\end{tabular}

${ }^{\dagger}$ Category abbreviations: $\mathrm{PHMI}=$ Physical human-made infrastructure, $\mathrm{II}=$ Institutional infrastructure, $\mathrm{BT}=\mathrm{Biophysical}$ traits, $\mathrm{CA} / \mathrm{OP}=\mathrm{Obstacles}$ to collective action/other pathways.

leakage leading to slower average water flow and increased variability.

Rules that are well-crafted to fit local conditions and agreed upon by resource users are anticipated to facilitate collective action and effective stewardship (Lam 1998). Because each of the analyzed CWPs has been given autonomy to devise its own rules, we hypothesized that governance regimes imposing more water use restrictions would associate with stronger water delivery outcomes (i.e., higher average water flow and lower flow variability), whereas fewer restrictions would represent a missed opportunity to organize water management responsibilities and would therefore detract from household-level water delivery (Table 5). This hypothesis was dependent on the assumption that resource managers within the study area are well informed and willing to make decisions in the best interests of their constituents; we attempted to capture resource manager knowledge of member concerns with the variable "Meeting attendance." The decision of a water manager to curb a CWP's membership growth (i.e., a "No" response to "Membership change") was believed to be the product of a well-calculated weighing of information concerning water supply against an understanding of CWP water demand. Better access and utilization of information by CWP decision makers to make difficult decisions with respect to membership growth was anticipated to result in strong resource allocation outcomes (e.g., Agrawal and Gupta 2005). A CWP employing a wet season water rotation schedule was expected to lower average household water flow and increase household flow variability because, in some CWPs, the need to rotate water during the wet season represents membership growth beyond an optimal level.

It should be noted here that all of the independent variables in the institutional infrastructure category were reported to us by the CWP managers as "rules-in-use." In other words, these are rules that, according to the managers, are truly employed on-theground. The reason we make this distinction here is to separate these rules from formal practices that may exist on paper but are not enforced in practice.

The anticipated relationships between the biophysical drivers and the water flow outcomes simply reflect the expectation that resource delivery would improve in the presence of a steeper elevation gradient (Table 5).

Finally, we offer hypothesized relationships for the variables within the "Other pathways" category (Table 5). Larger memberships were expected to hinder water delivery due to the association with increasing coordination and organizational challenges (Hardin 1982), more heterogeneous groups were also expected to hinder water delivery due to challenges posed to trust and cooperation (Ostrom 2005), and an increasing number of water storage devices was expected to lead a household to devalue their user group as water could be provided through multiple sources. In this category, we have also included "Years at residence" and "Meeting attendance," which were both intended to capture individual engagement in CWP responsibilities. A longstanding member who frequently participates in community meetings was expected to be more engaged in repairing physical infrastructure and reporting flow problems, and would therefore be expected to have higher household flow rates and lower flow variabilities (Kopelman et al. 2002, Lockwood et al. 2010). Additionally, an engaged member who attends multiple meetings is able to transfer valuable CWP branch or zonal information to those at the management level who are responsible for making upkeep and repair decisions (Ostrom and Gardner 1993). 


\section{Multilevel model description}

Multilevel regression models were developed due to the hierarchy of predictor variables. These models are a complex class of ordinary least squares (OLS) regression, but unlike OLS analysis, multilevel regressions allow for relationships both within and between multiple levels of grouped data to be inspected (Woltman et al. 2012). In the present analysis, two hierarchical levels exist: households (level 1) and CWPs (level 2). We did not include the WRUAs as a third level in our model for two reasons. First, the 25 CWPs from which we surveyed households are located in five WRUAs; thus, the number of groups within a third level would have been only five, potentially biasing the results due to the low count (Kreft and de Leeuw 1998, Maas and Hox 2007). Second, although the WRUA structures water-sharing schedules during the dry season, its role ostensibly ceases once water is withdrawn from the river by the CWP. And because WRUA water-sharing schedules are inflexible (J. Mwangi, personal communication)that is, they do not change during the year - the WRUAs ultimate influence on household-level water delivery is likely minimal in comparison to the role of the CWP. Both of the level 1 dependent variables in the model, average water flow and $\mathrm{CV}$ of water flow, were logged to create normal distributions.

To demonstrate the model, consider Eq. (1):

$$
\begin{aligned}
Y_{i j}=\beta_{0} X_{0}+\sum_{p=1}^{p} \beta_{p} X_{i j p}+\sum_{q=1}^{Q} \gamma_{q} Z_{j q} \\
+\sum_{j=1}^{J}\left(u_{j o} Z_{j o}+u_{j 1} Z_{j 1}\right)+e_{i j}
\end{aligned}
$$

Where:

$\mathrm{Y}_{\mathrm{ij}}=$ dependent variable measured for the $i$ th household nested within the $j$ th CWP;

$\beta_{0}=$ intercept parameter;

$\mathrm{X}_{0}=$ indicator for the intercept parameter;

$\beta_{\mathrm{p}}=$ household-level parameter capturing the model's fixed effects;

$\gamma_{\mathrm{q}}=$ CWP level parameter capturing the model's fixed effects;

$\mathrm{X}_{\mathrm{ijp}}=$ the $p$ th predictor depicting the household characteristics;

$\mathrm{Z}_{\mathrm{jq}}=$ the $q$ th predictor depicting the CWP characteristics;

$\mathrm{u}_{\mathrm{j} 0}=$ random effects of the $j$ th CWP on the intercept;

$\mathrm{u}_{\mathrm{j} 1}=$ random effects of the $j$ th CWP on the slope;

$\mathrm{Z}_{\mathrm{j} 0}=$ indicators for the $j$ th CWP's random intercept;

$\mathrm{Z}_{\mathrm{j} 1}=$ indicators for the $j$ th CWP's random slope;

$\mathrm{e}_{\mathrm{ij}}=$ random error term associated with the $i$ th household nested within the $j$ th CWP.

Fixed effects, or values that do not vary across groups, were captured at the household level with $\beta_{\mathrm{p}}$ and at the CWP level with $\gamma_{\mathrm{q}}$ The $X_{\mathrm{ijp}}$ and $Z_{\mathrm{jq}}$ terms represented the household-level and CWP-level predictors, respectively. Random effects, or values that are allowed to vary across groups, were captured at the household level by $\mathrm{e}_{\mathrm{ij}}$ and at the CWP level with $\mathrm{u}_{\mathrm{j} 0}$ and $\mathrm{u}_{\mathrm{j} 1}$.

We used SAS's MIXED procedure to perform the analysis and restricted maximum likelihood (REML) to estimate the parameters. The REML method has been shown to produce more accurate estimates of random effects (Twisk 2006). A covariance structure was specified given the presence of random effects. We experimented with several covariance structures and settled on the "variance components" structure. In building the multilevel model, we followed the suggestion of Raudenbush and Bryk (2002): we initially defined all variables as fixed and then incrementally added them to the random statement until we found the best fit model. We tested for multicollinearity with these configurations of independent variables using the VIF option in SAS. All VIF values were below 10, suggesting that multicollinearity was not an issue.

\section{RESULTS}

All CWPs strive for equitable water distribution to members. For many CWPs, this is a core objective explicitly stated in their constitution, and it is presumed that every connection should receive the same amount of water. However, Table 6 illustrates the asymmetries that exist within the CWPs and the clear reality that achieving equitable distribution is exceedingly difficult. These results help to satisfy our second research question, which sought to understand disparities of water delivery within and between communities. All CWPs had at least one household with a flow variability (i.e., $\mathrm{CV}$ of water flow) that was at least one standard deviation greater than the CWP's mean variability (represented in Table 6 as the percentage of all surveyed households in a particular CWP with mean variability greater than one standard deviation of the CWP's mean variability). In other words, if one standard deviation is taken as the cutoff between acceptable and inadequate dependability of water delivery, then no CWP appears to be delivering water at a consistency that is acceptable to all members. There also does not appear to be a clear trend in terms of dependability of flow for CWPs of the same WRUA. For instance, the Nanyuki WRUA includes Nan-CWP-3, which had the smallest percentage of sampled households with inadequate dependability; however, it also includes Nan-CWP-5, which had the largest percentage of households with inadequate dependability. We acknowledge that water asymmetries could be further investigated by comparing household water supply to household water demand, as some households, such as those that are heavy irrigators, will demand more water than others. This was not analyzed in the current article because we were primarily interested in understanding the "supply" of water within CWPs, i.e., the drivers of water delivery and inequities in water delivery. We anticipate investigating water supply asymmetries alongside water demand in future analyses.

In terms of average flow rate, households also experience a range of outcomes (Table 6). For instance, the average household flow rate in NN-CWP-5, a CWP covering an area of $57.6 \mathrm{~km}^{2}$, was 8 L per minute, whereas Ngu-CWP-1, which occupies only $0.2 \mathrm{~km}^{2}$, had an average flow rate of $44 \mathrm{~L}$ per minute. As was true with flow variability, asymmetries of flow rate were present not only between CWPs, but also within them. Of the $25 \mathrm{CWPs}$, only six were able to deliver water to all households at a rate that was within one standard deviation of the CWP mean flow rate. In two CWPs, nearly a third of surveyed households were receiving water at a rate one standard deviation below the CWP mean flow rate, and in an additional $11 \mathrm{CWPs}$, water flow rate was below the one standard deviation benchmark for at least $15 \%$ of households. 
Table 6. CWP water asymmetries

\begin{tabular}{|c|c|c|c|}
\hline$\overline{\text { CWP name }^{\dagger}}$ & $\begin{array}{c}\text { WRUA } \\
\text { abbreviation }\end{array}$ & $\begin{array}{c}\text { Average flow rate (L/min) } \\
\text { (Percentage of sampled households with average } \\
\text { flow rate } 1 \text { standard deviation below CWP mean } \\
\text { flow rate) }\end{array}$ & $\begin{array}{c}\text { Average CV of water flow } \\
\text { (Percentage of sampled households with } \\
\text { average CV of water flow } 1 \text { standard deviation } \\
\text { above CWP mean variability of flow) }\end{array}$ \\
\hline L-CWP-1 & $\mathrm{L}$ & $13.0866(0 \%)$ & $0.3960(25 \%)$ \\
\hline L-CWP-2 & $\mathrm{L}$ & $12.7313(18 \%)$ & $0.1667(18 \%)$ \\
\hline L-CWP-3 & $\mathrm{L}$ & $11.5201(7 \%)$ & $0.2589(7 \%)$ \\
\hline L-CWP-4 & $\mathrm{L}$ & $8.7187(17 \%)$ & $0.3040(17 \%)$ \\
\hline L-CWP-5 & $\mathrm{L}$ & $10.0539(18 \%)$ & $0.2001(18 \%)$ \\
\hline Nan-CWP-1 & Nan & $7.5175(10 \%)$ & $0.3506(10 \%)$ \\
\hline Nan-CWP-2 & Nan & $16.7484(0 \%)$ & $0.3951(20 \%)$ \\
\hline Nan-CWP-3 & Nan & $13.7884(24 \%)$ & $0.2323(6 \%)$ \\
\hline Nan-CWP-4 & Nan & $43.4037(0 \%)$ & $0.2736(22 \%)$ \\
\hline Nan-CWP-5 & Nan & $17.0160(17 \%)$ & $0.4679(25 \%)$ \\
\hline Ngu-CWP-1 & $\mathrm{Ngu}$ & $44.0366(0 \%)$ & $0.2277(22 \%)$ \\
\hline Ngu-CWP-2 & $\mathrm{Ngu}$ & $14.7535(0 \%)$ & $0.2612(11 \%)$ \\
\hline Ngu-CWP-3 & $\mathrm{Ngu}$ & $15.2452(29 \%)$ & $0.2134(14 \%)$ \\
\hline Ngu-CWP-4 & $\mathrm{Ngu}$ & $24.1239(20 \%)$ & $0.2576(15 \%)$ \\
\hline Ngu-CWP-5 & $\mathrm{Ngu}$ & $11.5243(16 \%)$ & $0.2595(11 \%)$ \\
\hline NN-CWP-1 & $\mathrm{NN}$ & $41.4151(0 \%)$ & $0.1913(16 \%)$ \\
\hline NN-CWP-2 & $\mathrm{NN}$ & $11.7590(16 \%)$ & $0.2865(21 \%)$ \\
\hline NN-CWP-3 & NN & $15.8447(6 \%)$ & $0.1700(6 \%)$ \\
\hline NN-CWP-4 & $\mathrm{NN}$ & $25.5290(30 \%)$ & $0.4806(10 \%)$ \\
\hline NN-CWP-5 & NN & $8.0075(18 \%)$ & $0.4012(18 \%)$ \\
\hline T-CWP-1 & $\mathrm{T}$ & $11.3636(5 \%)$ & $0.3221(11 \%)$ \\
\hline T-CWP-2 & $\mathrm{T}$ & $20.8532(22 \%)$ & $0.1630(17 \%)$ \\
\hline T-CWP-3 & $\mathrm{T}$ & $22.2708(12 \%)$ & $0.3011(18 \%)$ \\
\hline T-CWP-4 & $\mathrm{T}$ & $17.8944(19 \%)$ & $0.3147(19 \%)$ \\
\hline T-CWP-5 & $\mathrm{T}$ & $22.8324(8 \%)$ & $0.2640(17 \%)$ \\
\hline
\end{tabular}

Pseudonym used for CWP name.

${ }^{\ddagger}$ WRUA abbreviation - L=Likii, Nan=Nanyuki, Ngu=Ngusishi, NN=Ngare Nything, T=Timau.

With evidence clearly suggesting that CWP water distribution is heterogeneous both within and between CWPs, the multilevel regression models were used to understand the contextual elements that drive these water delivery outcomes. Furthermore, with the regression models accounting for the broader CIS, rather than predominately focusing on the institutional structure, and with performance assessed using household-level water delivery data, rather than relying on a proxy for performance, the results are intended to offer explanations for resource delivery that have yet to be provided in the common-pool resource literature. These multilevel regression results help to satisfy our first research question, which sought to understand how elements of the CIS influence water delivery. Examining first the model with the log of average household flow rate as the dependent variable (Table 7), the challenge of delivering an adequate amount of water to households to meet their farming needs is significantly associated with several traits from the "Physical human-made infrastructure" category. Households that are within older CWPs possessing more distribution lines appear to have higher average household water flow rates. This contradicts two of our proposed hypotheses from Table 5 and suggests that a CWP such as NNCWP-5 (established in 1972 with 24 distribution lines) may provide a superior rate of flow to its households compared with households within a CWP such as Ngu-CWP-5 (established in 2008 with eight distribution lines). Consistent with our hypothesized relationships, household flow rates were higher when water traverses a shorter distance and a steeper elevation gradient, both from the river to the CWP intake and from the
CWP head-end to the homestead (from the "Biophysical traits" category, although only significant at the 0.10 level). Thus, a household positioned at the tail-end of the system infrastructure in Ngu-CWP-2 (total length of distribution lines: 22,157 m) on average experiences lower flow rates than a household at the tailend of the Ngu-CWP-3 system (total length: $834 \mathrm{~m}$ ).

Within the "Institutional infrastructure" category, the significant relationships suggest that household water flow rates are higher within CWPs that allow membership to grow and enforce a smaller set of sanctions for pipe damaging. These two associations counter hypotheses from Table 5, which anticipated that CWP performance would be improved if there were fewer households to distribute water to (i.e., capping membership) and managers were willing to craft a range of sanctioning strategies to counter illegal activities. Finally, within the "Collective action / other pathways" category, total membership is negatively associated with household flow rate. This relationship is consistent with our hypothesis that collective action may be challenged by a larger membership group, resulting in poorer water delivery.

Examining the second multilevel regression model (Table 8), which used the log of household CV of water flow as the dependent variable, only one variable within the "Physical human-made infrastructure" category was found to be significant: the number of distribution lines. This association suggests that households within a CWP with more distribution lines will have less dependable water flow, which is consistent with our hypothesis from Table 5 . Therefore, despite households within 
Table 7. Multilevel model results: average household flow rate

\begin{tabular}{|c|c|c|c|c|c|c|}
\hline \multirow{2}{*}{ Category $^{\dagger}$} & \multirow{2}{*}{$\begin{array}{l}\text { Parameter } \\
\text { Intercept }\end{array}$} & \multirow{2}{*}{$\begin{array}{c}\text { Estimate } \\
2.421\end{array}$} & \multirow{2}{*}{$\begin{array}{c}\begin{array}{c}\text { Standard } \\
\text { Error }\end{array} \\
0.465\end{array}$} & \multirow{2}{*}{$\begin{array}{c}p \\
<0.001\end{array}$} & \multicolumn{2}{|c|}{$95 \% \mathrm{CI}$} \\
\hline & & & & & 1.4595 & 3.3815 \\
\hline \multirow{6}{*}{ PHMI } & Areal coverage of $\mathrm{CWP}^{\mathrm{CWP}}$ & -0.014 & 0.009 & 0.110 & -0.0310 & 0.0032 \\
\hline & Number of distribution lines ${ }^{\mathrm{CWP}}$ & 0.025 & 0.010 & 0.015 & 0.0049 & 0.0445 \\
\hline & Pipe size at water source abstraction point ${ }^{\mathrm{CWP}}$ & 0.013 & 0.049 & 0.794 & -0.0832 & 0.1087 \\
\hline & Distance water source to head-end ${ }^{\mathrm{CWP}}$ & 0.000 & 0.000 & 0.386 & -0.0000 & 0.0001 \\
\hline & Age of CWP ${ }^{\text {CWP }}$ & 0.023 & 0.009 & 0.010 & 0.0055 & 0.0395 \\
\hline & Distance head-end to household ${ }^{\mathrm{HH}}$ & -0.000 & 0.000 & 0.034 & -0.0001 & -0.0000 \\
\hline \multirow{7}{*}{ II } & Membership change ${ }^{\text {CWP }}$ & 0.255 & 0.126 & 0.043 & 0.0076 & 0.5031 \\
\hline & Wet season rotation ${ }^{\mathrm{CWP}}$ & 0.091 & 0.131 & 0.484 & -0.1654 & 0.3483 \\
\hline & Membership criteria: Total conditions ${ }^{\mathrm{CWP}}$ & 0.022 & 0.130 & 0.867 & -0.2329 & 0.2763 \\
\hline & Pipe damaging: Total sanctions ${ }^{\mathrm{CWP}}$ & -0.158 & 0.080 & 0.048 & -0.3157 & -0.0012 \\
\hline & Failure to pay fee: Total sanctions ${ }^{\mathrm{CWP}}$ & -0.169 & 0.151 & 0.264 & -0.4655 & 0.1282 \\
\hline & Failure to work: Total sanctions ${ }^{\mathrm{CWP}}$ & -0.198 & 0.130 & 0.130 & -0.4547 & 0.0587 \\
\hline & Water use monitoring: Total entities ${ }^{\mathrm{CWP}}$ & -0.072 & 0.068 & 0.286 & -0.2067 & 0.0612 \\
\hline \multirow[t]{2}{*}{ BT } & Elevation gradient water source to intake ${ }^{\mathrm{CWP}}$ & 3.516 & 2.011 & 0.080 & -0.4234 & 7.4552 \\
\hline & Elevation gradient intake to household ${ }^{\mathrm{HH}}$ & 2.867 & 1.516 & 0.060 & -0.1174 & 5.8515 \\
\hline \multirow{9}{*}{$\mathrm{CA} / \mathrm{OP}$} & Total members ${ }^{\mathrm{CWP}}$ & -0.001 & 0.000 & 0.015 & -0.0017 & -0.0002 \\
\hline & Count of tribes ${ }^{\mathrm{CWP}}$ & 0.085 & 0.053 & 0.110 & -0.0194 & 0.1894 \\
\hline & Count of water storage devices ${ }^{\mathrm{HH}}$ & 0.004 & 0.035 & 0.915 & -0.0642 & 0.0716 \\
\hline & Years at residence ${ }^{\mathrm{HH}}$ & -0.000 & 0.002 & 0.863 & -0.0037 & 0.0031 \\
\hline & Meeting attendance ${ }^{\mathrm{HH}, *}$ & & & & & \\
\hline & -Never & -0.101 & 0.199 & 0.615 & -0.5120 & 0.3096 \\
\hline & -Once & -0.212 & 0.131 & 0.119 & -0.4820 & 0.0584 \\
\hline & $-6+$ times & -0.041 & 0.097 & 0.673 & -0.2420 & 0.1592 \\
\hline & Sample size & 370 & & & & \\
\hline
\end{tabular}

numerous-lined CWPs such as NN-CWP-5 having higher flow rates on average, as suggested by the previous regression model, the reliability of water delivery to these same households may be poorer.

Within the "Institutional infrastructure" category, households belonging to CWPs imposing wet season water rotations and a smaller set of sanctions for failing to pay the CWP's monthly maintenance fee were found to have more reliable household water flow. These relationships challenge our proposed hypotheses and suggest that a household within a CWP such as L-CWP-3, which rotates water between members during the wet season, may have more reliable water delivery than a household within a CWP that never rotates water. Additionally, a larger set of conditions needed to be filled to join a CWP appears to associate with more reliable flow, which, in this case, is consistent with our proposed hypotheses (although this variable is only significant at the 0.10 level).

Finally, with respect to the "Collective action / other pathways" category, more heterogeneous memberships associate with more reliable water delivery. This relationship again challenges one of our proposed hypotheses, which anticipated that the more dissimilar a group, the more difficult it would be for individuals to collectively solve appropriation and provision dilemmas, thus resulting in less reliable water delivery. In the next section, we provide additional perspective to these results by discussing potential causality concerns, which may offer explanations for some of the confounding relationships.

In terms of the practical significance of the predictor variables from Tables 7 and 8 , we have calculated each variable's marginal effect to estimate the effect of a one-standard-deviation increase in the predicator variables (Table 9). We produced these estimates in a similar fashion as Cox and Ross (2011): the standard deviation of each predictor variable from Table 4 was multiplied by the coefficients derived from the multilevel regressions (Tables 7 and 8 ) to estimate the marginal effect. These values were then divided by the standard deviation of the outcome variables to calculate the percentage of the outcome variables' standard deviation accounted for within the marginal effect. For instance, the marginal effect of the number of distribution lines in the model explaining CV of water flow is $0.160(0.021 * 7.632)$, which represents $90 \%$ of the standard deviation of $\mathrm{CV}$ of water flow $(0.160 / 0.1782)$. Table 9 indicates that the marginal effects of the predictor variables in the average flow rate model are quite small given the wide range in household flow rates. In terms of the $\mathrm{CV}$ of water flow, the percentage of the dependent variable's standard 
Table 8. Multilevel model results: CV of water flow

\begin{tabular}{|c|c|c|c|c|c|c|}
\hline \multirow{2}{*}{ Category $^{\dagger}$} & \multirow{2}{*}{$\begin{array}{l}\text { Parameter } \\
\text { Intercept }\end{array}$} & \multirow{2}{*}{$\begin{array}{c}\text { Estimate } \\
-0.164\end{array}$} & \multirow{2}{*}{$\begin{array}{c}\begin{array}{c}\text { Standard } \\
\text { Error }\end{array} \\
0.456\end{array}$} & \multirow{2}{*}{$\begin{array}{c}p \\
0.721\end{array}$} & \multicolumn{2}{|c|}{$95 \% \mathrm{CI}$} \\
\hline & & & & & -1.0823 & 0.7544 \\
\hline \multirow{6}{*}{ PHMI } & Areal coverage of $\mathrm{CWP}^{\mathrm{CWP}}$ & 0.012 & 0.008 & 0.169 & -0.0050 & 0.0066 \\
\hline & Number of distribution lines ${ }^{\mathrm{CWP}}$ & 0.021 & 0.010 & 0.029 & 0.0022 & 0.0405 \\
\hline & Pipe size at water source abstraction point ${ }^{\mathrm{CWP}}$ & -0.060 & 0.046 & 0.197 & -0.1495 & 0.0309 \\
\hline & Distance water source to head-end ${ }^{\text {CWP }}$ & -0.000 & 0.000 & 0.970 & -0.0001 & 0.0001 \\
\hline & Age of CWP ${ }^{C W P}$ & -0.009 & 0.008 & 0.253 & -0.0249 & 0.0066 \\
\hline & Distance head-end to household ${ }^{\mathrm{HH}}$ & 0.000 & 0.000 & 0.410 & -0.0000 & 0.0001 \\
\hline \multirow{7}{*}{ II } & Membership change ${ }^{\text {CWP }}$ & -0.139 & 0.119 & 0.246 & -0.3730 & 0.0961 \\
\hline & Wet season rotation ${ }^{\mathrm{CWP}}$ & -0.339 & 0.127 & 0.008 & -0.5889 & -0.0890 \\
\hline & Membership criteria: Total conditions ${ }^{\mathrm{CWP}}$ & -0.228 & 0.123 & 0.065 & -0.4694 & 0.0144 \\
\hline & Pipe damaging: Total sanctions ${ }^{\text {CWP }}$ & 0.038 & 0.074 & 0.603 & -0.1065 & 0.1833 \\
\hline & Failure to pay fee: Total sanctions ${ }^{\mathrm{CWP}}$ & 0.297 & 0.138 & 0.032 & 0.0257 & 0.5689 \\
\hline & Failure to work: Total sanctions ${ }^{\mathrm{CWP}}$ & -0.016 & 0.120 & 0.895 & -0.2520 & 0.2204 \\
\hline & Water use monitoring: Total entities ${ }^{\mathrm{CWP}}$ & -0.084 & 0.066 & 0.203 & -0.2138 & 0.0456 \\
\hline \multirow[t]{2}{*}{ BT } & Elevation gradient water source to intake ${ }^{\mathrm{CWP}}$ & -1.641 & 1.898 & 0.388 & -5.3758 & 2.0948 \\
\hline & Elevation gradient intake to household ${ }^{\mathrm{HH}}$ & 0.489 & 1.877 & 0.795 & -3.2039 & 4.1823 \\
\hline \multirow{9}{*}{$\mathrm{CA} / \mathrm{OP}$} & Total members ${ }^{\mathrm{CWP}}$ & 0.000 & 0.000 & 0.390 & -0.0004 & 0.0011 \\
\hline & Count of tribes ${ }^{\mathrm{CWP}}$ & -0.110 & 0.051 & 0.033 & -0.2103 & -0.0091 \\
\hline & Count of water storage devices ${ }^{\mathrm{HH}}$ & -0.074 & 0.047 & 0.113 & -0.1654 & 0.0176 \\
\hline & Years at residence $\mathrm{HH}^{\mathrm{HH}}$ & -0.000 & 0.002 & 0.890 & -0.0049 & 0.0043 \\
\hline & Meeting attendance ${ }^{\mathrm{HH}, *}$ & & & & & \\
\hline & Never & -0.081 & 0.192 & 0.672 & -0.4588 & 0.2960 \\
\hline & Once & -0.025 & 0.113 & 0.822 & -0.2475 & 0.1966 \\
\hline & $6+$ times & -0.099 & 0.089 & 0.264 & -0.2735 & 0.0751 \\
\hline & Sample size & 370 & & & & \\
\hline
\end{tabular}

deviation is much larger. This results from a narrower range between households with particularly reliable flow and households with particularly unreliable flow. Although both models are valuable in understanding the contextual elements driving water delivery outcomes, Table 9 suggests the predictor variables to be more effective in explaining changes in the $\mathrm{CV}$ of water flow than average household water flow rate.

\section{DISCUSSION}

\section{Causality within a coupled infrastructure system}

In this study, we queried elements from the CIS's institutional, physical human-made, and biophysical infrastructures to evaluate resource provisioning by way of two multilevel models, which helped to satisfy our first research question. By including institutional, technological, and biophysical traits, a challenge emerged in interpreting our results related to the issue of causality. In explaining the issue of causality in CPR studies, Anderies et al. (2016) return to the idea that institutional arrangements have been favored in explanations of resource outcomes, and they go on to state that in some cases the assemblage of these institutional traits may actually be the product of dynamics within the CIS, not the treatment prescribed to remedy an unwanted resource outcome. In other words, the institutional infrastructure in some cases needs to be viewed as "emerging from" rather than being "assigned to" a particular situation (Anderies et al. 2016: 508). To demonstrate this further, we draw on one of the confounding relationships returned from the regression models.

Earlier, we hypothesized that household water flow rates would be lower within CWPs that enforced fewer sanctions for damaging CWP pipes. Our reasoning for this was as follows: more sanctions would lead to a more compliant CWP membership, which would ensure the integrity of pipes and result in superior performance outcomes, such as higher household flow rates. Yet, our regression model returned the opposite result, suggesting that fewer sanctions for damaging pipes associates with higher flow rates. We speculate, however, that this is an instance of reverse causality where the decision of the CWP management committee to impose fewer sanctions reflects the committee's understanding that, for example, the physical human-made infrastructure is well-cared for and elements of the biophysical context will not impede delivery of water. In other words, the limited number of sanctions does not result in higher flow rates; rather, the causal pathway is reversed: superior flow rates achieved by, potentially, fitness of the physical human-made and biophysical infrastructures have allowed the management committee to impose fewer sanctions without detracting from water delivery outcomes. Agrawal (2001) 
Table 9. Marginal effects

\begin{tabular}{|c|c|c|c|c|c|}
\hline \multirow[b]{2}{*}{ Category $^{\dagger}$} & \multirow[b]{2}{*}{ Parameter } & \multicolumn{2}{|c|}{ Average flow rate $(\mathrm{L} / \mathrm{min})$} & \multicolumn{2}{|c|}{$\mathrm{CV}$ of water flow } \\
\hline & & $\begin{array}{l}\text { Marginal } \\
\text { Effect }\end{array}$ & $\begin{array}{c}\% \text { DV's } \\
\text { standard deviation }\end{array}$ & $\begin{array}{l}\text { Marginal } \\
\text { Effect }\end{array}$ & $\begin{array}{c}\text { \% DV's } \\
\text { standard } \\
\text { deviation }\end{array}$ \\
\hline \multirow{6}{*}{ PHMI } & Areal coverage of $\mathrm{CWP}^{\mathrm{CWP}}$ & -0.170 & $-1.17 \%$ & 0.145 & $81.62 \%$ \\
\hline & Number of distribution lines ${ }^{\mathrm{CWP}}$ & 0.191 & $1.32 \%$ & 0.160 & $89.94 \%$ \\
\hline & Pipe size at water source abstraction point ${ }^{\mathrm{CWP}}$ & 0.021 & $0.14 \%$ & -0.096 & $-53.60 \%$ \\
\hline & Distance water source to head-end ${ }^{\text {CWP }}$ & 0.104 & $0.72 \%$ & -0.004 & $-2.34 \%$ \\
\hline & Age of CWP ${ }^{\mathrm{CWP}}$ & 0.207 & $1.43 \%$ & -0.081 & $-45.39 \%$ \\
\hline & Distance head-end to household ${ }^{\mathrm{HH}}$ & -0.069 & $-0.48 \%$ & 0.032 & $17.85 \%$ \\
\hline \multirow{7}{*}{ II } & Membership change ${ }^{\mathrm{CWP}}$ & 0.119 & $0.82 \%$ & -0.065 & $-36.39 \%$ \\
\hline & Wet season rotation ${ }^{\mathrm{CWP}}$ & 0.042 & $0.29 \%$ & -0.158 & $-88.75 \%$ \\
\hline & Membership criteria: Total conditions ${ }^{\mathrm{CWP}}$ & 0.013 & $0.09 \%$ & -0.131 & $-73.45 \%$ \\
\hline & Pipe damaging: Total sanctions ${ }^{\mathrm{CWP}}$ & -0.126 & $-0.87 \%$ & 0.031 & $17.06 \%$ \\
\hline & Failure to pay fee: Total sanctions ${ }^{\mathrm{CWP}}$ & -0.116 & $-0.80 \%$ & 0.204 & $114.70 \%$ \\
\hline & Failure to work: Total sanctions ${ }^{\mathrm{CWP}}$ & -0.102 & $-0.70 \%$ & -0.008 & $-4.61 \%$ \\
\hline & Water use monitoring: Total entities ${ }^{\mathrm{CWP}}$ & -0.091 & $-0.63 \%$ & -0.106 & $-59.63 \%$ \\
\hline \multirow[t]{2}{*}{ BT } & Elevation gradient water source to intake ${ }^{\mathrm{CWP}}$ & 0.105 & $0.73 \%$ & -0.049 & $-27.53 \%$ \\
\hline & Elevation gradient intake to household ${ }^{\mathrm{HH}}$ & 0.065 & $0.45 \%$ & 0.011 & $6.26 \%$ \\
\hline \multirow{4}{*}{$\mathrm{CA} / \mathrm{OP}$} & Total members & -0.238 & $-1.65 \%$ & 0.078 & $43.64 \%$ \\
\hline & Count of tribes ${ }^{\mathrm{CWP}}$ & 0.084 & $0.58 \%$ & -0.109 & $-61.28 \%$ \\
\hline & Count of water storage devices ${ }^{\mathrm{HH}}$ & 0.003 & $0.02 \%$ & -0.047 & $-26.53 \%$ \\
\hline & Years at residence $^{\mathrm{HH}}$ & -0.003 & $-0.02 \%$ & -0.004 & $-2.01 \%$ \\
\hline
\end{tabular}

similarly recognized that researchers needed to be cognizant of reverse causality in CPR-based case studies that predominately focused on institutional arrangements. In expanding our focus beyond the institutional infrastructure, our analysis provides new understandings of the causality issues raised both by Agrawal (2001) and Anderies et al. (2016) Furthermore, inclusion of elements from a broader CIS helps to avoid the spurious correlation fallacy: erroneously linking a particular outcome to a variable under study when the true relationship is with an omitted variable. Such is the risk of analyses that focus on the institutional infrastructure while overlooking other elements of the CIS.

\section{Information exchange to improve outcomes}

For the management committee of a CWP — or any of the various CPR user groups around the globe - to understand which households are receiving poor water delivery and the contributing forces of the CIS leading to this outcome, household-level information is needed. We indicated earlier that financial and technological issues impede the use of flow sensors on household water distribution lines. In the absence of these measurement devices, branch or zonal representatives are responsible for reporting flow obstruction issues to their CWP management committee. This acts as an important information transfer intended to improve household water delivery. In the regression models, we included a variable for the number of times in a year that a household attended a meeting on water-related issues. In the absence of comprehensive data concerning the branch representatives and their duties, we believed that this variable would be an adequate alternative: an individual who is particularly concerned with water-related issues would be more likely to report such concerns to the management committee and, therefore, more likely to have better flow outcomes. We were surprised that this variable was insignificant in both of the regression models given the importance of knowledge transfers as it was explained to us during fieldwork. In fact, when a subset of the management committees were asked about the proceedings of their general meetings, 15 of 18 committees stated that complaints of low water flow were regularly voiced by branch representatives during these meetings. A subsequent review of the bylaws and constitutions that could be obtained from the CWP committees revealed that 11 of 14 CWPs had positions on their committees specifically devoted to branch representatives charged with relaying constituent concerns.

It is possible that a variable better targeted at the relationship between branch representatives and management committees may have identified an information exchange signal. It may also be the case that this signal is captured in the significant relationship found between total membership size and household flow rate, which associates households within larger membership CWPs with lower flow rates (see Table 7). Studies such as Agrawal and Goyal (2001) have demonstrated that collective action can be challenged by group size. In our analysis, larger memberships may make coordination more difficult and obstruct formation of trust amongst membership. Information exchange between branch representatives and the CWP management committee may be one of the areas in which coordination difficulties result in water 
asymmetries. In this vein, we could expect communication within a CWP such as NN-CWP-4, which has 25 members, to be more fluid than within a CWP such as Nan-CWP-2, which has over 800 members. If this is true, then the information exchange signal may be captured within the relationship between membership size and water delivery.

The inability of CWP management committees to possess household-level water delivery data, as well as the limited information concerning associations between CIS elements and water delivery, suggests that consistent meetings of membership and strong communication with the management committee may constitute the most effective strategies for resolving poor water delivery outcomes. The broad range of elements making up the CIS do seem to be common topics discussed during CWP meetings. Eight CWP management committees indicated that the condition of the physical human-made infrastructure is frequently discussed with their memberships and that assessments of the fitness of distribution lines are carried out whenever decisions to add new members are made. Topics discussed during these meetings include the age of the physical infrastructure and the number of distribution lines already existing on a particular branch. The institutional infrastructure also receives attention during these meetings. For example, evaluations of when to begin rotating water between distribution lines during the dry season critically impacts farmer planting and harvesting decisions. As the rainy season wanes, meetings are commonly held with CWP memberships to assess climate information provided by higher levels of governance (such as the catchment level WRUA) in order to evaluate the water rotation rule set. Finally, communication both among user group members as well as between these members and the management committee appears to be a priority of these meetings. Aside from individuals reporting water flow concerns at these general meetings, users will also address their concerns about the actions of other CWP members. In 13 of 18 interviews within management committees, grievances about the actions of another member, such as an individual's excessive water use or failure to keep a particular distribution line in good repair, were stated to be a common item at their general meetings. These channels for communication help to address collective action dilemmas when they arise and offer means by which water delivery concerns are addressed.

\section{Conclusion}

Managing a complex resource system relies on a wide swath of information about the CIS. This study demonstrated relationships between water delivery and a range of elements constituting the physical human-made, institutional, and biophysical infrastructures of 25 CWPs in the Mount Kenya region. In describing these relationships, we addressed causality issues as well as the role of information sharing in ensuring the success of a user group. As it relates to sharing of information, the importance of this action can be summarized as follows: due to the absence of real-time household-level data to assess CWP performance, information sharing offers opportunities for members to relay concerns of poor flow and address issues they may have with the state of physical and institutional infrastructure.

We believe that this study makes several important contributions to the CPR literature, as well as the broader social-ecological systems (SES) literature, which we have repositioned around CISs.
First, we have conducted an assessment of user group performance by employing household-level data that avoids the use of a proxy variable. In estimating user group performance, we feel this is important in order to avoid complications introduced by intervening variables. Second, we address two commonly stated concerns within the SES literature: that biophysical elements are underrepresented and that the significance assigned to institutional attributes when evaluating system outcomes is regularly overstated. Finally, we speak to the importance of communication and information sharing in the absence of sophisticated technologies geared toward evaluating resource provisioning. As it relates to research evaluating the successes and failures of CPR user groups, each of these contributions are ripe for further research and inquiry.

Responses to this article can be read online at: http://www.ecologyandsociety.org/issues/responses. $\mathrm{php} / 9156$

\section{Acknowledgments:}

We gratefully acknowledge support from the U.S. National Science Foundation (grant numbers: SES-1360463, SES-1360421, and BCS-1115009). Additionally, we thank the generous support of The Ostrom Workshop, which provided assistance through a 2015 Ostrom Research Award. Finally, we thank Michael Frisby of the Indiana Statistical Consulting Center for his assistance with the statistical models.

\section{LITERATURE CITED}

Agrawal, A. 2001. Common property institutions and sustainable governance of resources. World Development 29 (10):1649-1672. http://dx.doi.org/10.1016/s0305-750x(01)00063-8

Agrawal, A., and S. Goyal. 2001. Group size and collective action: third party monitoring in common-pool resources. Comparative Political Studies 34(1):63-93. http://dx.doi.org/10.1177/0010414$\underline{001034001003}$

Agrawal, A., and K. Gupta. 2005. Decentralization and participation: the governance of common pool resources in Nepal's Terai. World Development 33(7):1101-1114. http://dx.doi. org/10.1016/j.worlddev.2005.04.009

Anderies, J. M., M. A. Janssen, and E. Schlager. 2016. Institutions and the performance of coupled infrastructure systems. International Journal of the Commons 10(2):495-516. http://dx. doi.org/10.18352/ijc.651

Baldwin, E., C. Washington-Ottombre, J. Dell'Angelo, D. H. Cole, and T. Evans. 2016. Polycentric governance and irrigation reform in Kenya. Governance 29(2):207-225. http://dx.doi. org/10.1111/gove. 12160

Basurto, X., and E. Ostrom. 2009. Beyond the tragedy of the commons. Economia delle fonti di energia e dell'ambiente 52:3560 .

Berkes, F. 2002. Cross-scale institutional linkages: perspectives from the bottom up. Pages 293-321 in E. Ostrom, T. Dietz, N. 
Dolsak, P. C. Stern, S. Stovich, and E. U. Weber, editors, The drama of the commons. National Academy Press, Washington, D. C., USA.

Berkes, F., and C. Folke. 1994. Linking social and ecological systems for resilience and sustainability. Beijer Discussion Paper Series No. 52, Stockholm, Sweden.

Coop, P., and D. Brunckhorst. 1999. Triumph of the commons: age-old participatory practices provide lessons for institutional reform in the rural sector. Australian Journal of Environmental Management 6(2):69-77. http://dx.doi.org/10.1080/14486563.1999.10648453

Cox, M., and J. M. Ross. 2011. Robustness and vulnerability of community irrigation systems: the case of the Taos valley acequias. Journal of Environmental Economics and Management 61(3):254-266. http://dx.doi.org/10.1016/j.jeem.2010.10.004

Dell'Angelo, J., P. F. McCord, E. Baldwin, M. E. Cox, D. Gower, K. Caylor, and T. P. Evans. 2014. Multilevel governance of irrigation systems and adaptation to climate change in Kenya. Pages 323-342 in A. Bhaduri, J. Bogardi, J. Leentvaar, and S. Marx, editors. The global water system in the Anthropocene. Springer International Publishing, Cham, Switzerland. http://dx. doi.org/10.1007/978-3-319-07548-8_21

Dell'Angelo, J., P. F. McCord, D. Gower, S. Carpenter, K. K. Caylor, and T. P. Evans. 2016. Community water governance on Mount Kenya: an assessment based on Ostrom's design principles of natural resource management. Mountain Research and Development 36(1):102-115. http://dx.doi.org/10.1659/mrd-journald-15-00040.1

Epstein, G., J. M. Vogt, S. K. Mincey, M. Cox, and B. Fischer. 2013. Missing ecology: integrating ecological perspectives with the social-ecological system framework. International Journal of the Commons 7(2):432-453. http://dx.doi.org/10.18352/ijc.371

Gordon, H. S. 1954. The economic theory of a common-property resource: the fishery. Journal of Political Economy 62(2):124-142. http://dx.doi.org/https://doi.org/10.1086/257497

Hardin, G. 1968. The tragedy of the commons. Science 162 (3859):1243-1248. http://dx.doi.org/10.1080/19390450903037302

Hardin, R. 1982. Collective action: a book from resources for the future. The Johns Hopkins University Press, Baltimore, MD, USA.

Kopelman, S., J. M. Weber, and D. M. Messick. 2002. Factors influencing cooperation in commons dilemmas: a review of experimental psychological research. Pages 113-156 in E. Ostrom, T. Dietz, N. Dolsak, P. C. Stern, S. Stovich, and E. U. Weber, editors. The drama of the commons. National Academy Press, Washington, D.C., USA.

Kreft, I., and J. de Leeuw. 1998. Introducing multilevel modeling. Sage Publications, Thousand Oaks, California, USA. http://dx. doi.org/10.4135/9781849209366

Lam, W. F. 1996. Improving the performance of small-scale irrigation systems: the effects of technological investments and governance structure on irrigation performance in Nepal. World Development 24(8):1301-1315. http://dx.doi.org/10.1016/0305-750x (96)00043-5
Lam, W. F. 1998. Governing irrigation systems in Nepal: institutions, infrastructure, and collective action. ICS Press, Oakland, California, USA.

Liniger, H., J. Gikonyo, B. Kiteme, and U. Wiesmann. 2005. Assessing and managing scarce tropical mountain water resources: the case of Mount Kenya and the semiarid upper Ewaso Ng'iro basin. Mountain Research and Development 25 (2):163-173. http://dx.doi.org/10.1659/0276-4741(2005)025[0163: aamstm]2.0.co;2

Lockwood, M., J. Davidson, A. Curtis, E. Stratford, and R. Griffith. 2010. Governance principles for natural resource management. Society and Natural Resources 23(10):986-1001. http://dx.doi.org/10.1080/08941920802178214

Maas, C. J. M., and J. J. Hox. 2007. Sufficient sample sizes for multilevel modeling. Methodology 1(3):86-92. http://dx.doi.org/ https://doi.org/10.1027/1614-2241.1.3.86

Makurira, H., M. L. Mul, N. F. Vyagusa, S. Uhlenbrook, and H. H. G. Savenije. 2007. Evaluation of community-driven smallholder irrigation in dryland South Pare Mountains, Tanzania: a case study of Manoo micro dam. Physics and Chemistry of the Earth, Parts A/B/C 32(15-18):1090-1097. http:// dx.doi.org/10.1016/j.pce.2007.07.020

McCord, P. F., M. Cox, M. Schmitt-Harsh, and T. Evans. 2015. Crop diversification as a smallholder livelihood strategy within semi-arid agricultural systems near Mount Kenya. Land Use Policy 42:738-750. http://dx.doi.org/10.1016/j.landusepol.2014.10.012

McCord, P. F., J. Dell'Angelo, E. Baldwin, and T. Evans. 2016. Polycentric transformation in Kenyan water governance: a dynamic analysis of institutional and social-ecological change. Policy Studies Journal . http://dx.doi.org/10.1111/psj.12168

Molden, D. J., and T. K. Gates. 1990. Performance measures for evaluation of irrigation-water-delivery systems. Journal of Irrigation and Drainage Engineering 116(6):804-823. http://dx. doi.org/10.1061/(asce)0733-9437(1990)116:6(804)

Morrow, C. E., and R. W. Hull. 1996. Donor-initiated common pool resource institutions: the case of the Yanesha Forestry Cooperative. World Development 24(10):1641-1657. http://dx. doi.org/10.1016/0305-750x(96)00064-2

Ngigi, S. N., H. H. G. Savenije, and F. N. Gichuki. 2007. Land use changes and hydrological impacts related to up-scaling of rainwater harvesting and management in upper Ewaso Ng'iro river basin, Kenya. Land Use Policy 24:129-140. http://dx.doi. org/10.1016/j.landusepol.2005.10.002

Ostrom, E. 1990. Governing the commons: the evolution of institutions for collective action. Cambridge University Press, New York, New York, USA. http://dx.doi.org/https://doi.org/10.1017/ CBO9780511807763

Ostrom, E. 1992. Crafting institutions for self-governing irrigation systems. ICS Press, San Francisco, California, USA.

Ostrom, E. 2005. Understanding institutional diversity. Princeton University Press, Princeton, New Jersey, USA.

Ostrom, E. 2007. A diagnostic approach for going beyond panaceas. Proceedings of the National Academy of Sciences 104 (39):15181-15187. http://dx.doi.org/10.1073/pnas.0702288104 
Ostrom, E., and R. Gardner. 1993. Coping with asymmetries in the commons: self-governing irrigation systems can work. The Journal of Economic Perspectives 7(4):93-112. http://dx.doi. org/10.1257/jep.7.4.93

Raudenbush, S. W., and A. S. Bryk. 2002. Hierarchical linear models: applications and data analysis methods. Sage Publications, Thousand Oaks, California, USA.

Rissman, A. R., and S. Gillon. 2016. Where are ecology and biodiversity in social-ecological systems research? A review of research methods and applied recommendations. Conservation Letters 10(1):86-93. http://dx.doi.org/10.1111/conl.12250

Scott, A. 1955. The fishery: the objectives of sole ownership. Journal of Political Economy 63(2):116-124. http://dx.doi. org/10.1086/257653

Small, L. E., and M. Svendsen. 1990. A framework for assessing irrigation performance. Irrigation and Drainage Systems 4(4):283312. http://dx.doi.org/10.1007/bf01103710

Tucker, C. 1999. Evaluating a common property institution: design principles and forest management in a Honduran community. Praxis 15:47-76.

Twisk, J. W. R. 2006. Applied multilevel analysis: a practical guide. Cambridge University Press, Cambridge, UK. http://dx.doi. org/10.1017/cbo9780511610806

Vogt, J. M., G. Epstein, S. K. Mincey, B. Fischer, and P. F. McCord. 2015. Putting the "E" in SES: unpacking the ecology in the Ostrom social-ecological system framework. Ecology and Society 20 (1):55. http://dx.doi.org/10.5751/es-07239-200155

Woltman, H., A. Feldstain, J. C. MacKay, and M. Rocchi. 2012. An introduction to hierarchical linear modeling. Tutorials in Quantitative Methods for Psychology 8(1):52-69. http://dx.doi. org/10.20982/tqmp.08.1.p052

Young, O. R. 2002. Institutional interplay: the environmental consequences of cross-scale interactions. Pages ??? in E. Ostrom, T. Dietz, N. Dolsak, P. C. Stern, S. Stovich, and E. U. Weber, editors. The drama of the commons. National Academy Press, Washington, D.C., USA. 


\section{APPENDIX}

\begin{tabular}{|c|c|c|}
\hline Community Water Project & WRUA & $\begin{array}{l}\text { Number of Household } \\
\text { Surveys }\end{array}$ \\
\hline L-CWP-1 & \multirow{5}{*}{ Likii } & $25^{1}$ \\
\hline L-CWP-2 & & $21^{2}$ \\
\hline L-CWP-3 & & 32 \\
\hline L-CWP-4 & & 32 \\
\hline L-CWP-5 & & 30 \\
\hline Nan-CWP-1 & \multirow{5}{*}{ Nanyuki } & 30 \\
\hline Nan-CWP-2 & & $28^{1}$ \\
\hline Nan-CWP-3 & & $25^{2}$ \\
\hline Nan-CWP-4 & & 34 \\
\hline Nan-CWP-5 & & 38 \\
\hline Ngu-CWP-1 & \multirow{5}{*}{ Ngusishi } & $25^{2}$ \\
\hline Ngu-CWP-2 & & 30 \\
\hline Ngu-CWP-3 & & 30 \\
\hline Ngu-CWP-4 & & $11^{2}$ \\
\hline Ngu-CWP-5 & & $27^{2}$ \\
\hline NN-CWP-1 & \multirow{5}{*}{ Ngare Nything } & 32 \\
\hline NN-CWP-2 & & 32 \\
\hline NN-CWP-3 & & 36 \\
\hline NN-CWP-4 & & $20^{2}$ \\
\hline NN-CWP-5 & & $28^{2}$ \\
\hline T-CWP-1 & \multirow{5}{*}{ Timau } & 43 \\
\hline T-CWP-2 & & 35 \\
\hline T-CWP-3 & & 35 \\
\hline T-CWP-4 & & 31 \\
\hline T-CWP-5 & & 40 \\
\hline
\end{tabular}

${ }^{1}$ In these CWPs we were unable to sample 30 households due to logistical challenges related to the length of time it took to receive approval to begin surveying households.

${ }^{2}$ In these CWPs we only sampled $50 \%$ of the households since membership was considerably smaller. 